\title{
A review of electrophoretic patterns from a tertiary care nephrourology referral centre
}

\author{
Kowsalya Ramprasad ${ }^{1}$ and Sujatha Siddappa ${ }^{2}$ \\ 1 Department of Biochemistry, Institute of NephroUrology, Bangalore, Karnataka State, 560002, India \\ 2 Department of Pathology, Institute of NephroUrology, Bangalore, Karnataka State, 560002, India
}

\begin{abstract}
Protein electrophoresis is an easy, inexpensive test routinely used in clinical laboratories for screening protein abnormalities in various biological fluids. It is commonly used test to identify patients with multiple myeloma and other disorders of serum protein. Evaluation of patients with chronic kidney disease typically includes serum and urine protein electrophoresis. This retrospective study was undertaken to analyze the pattern of electrophoretic results at our exclusive nephrourology referral centre. All the patients who had been referred for electrophoresis (SPEP and UPEP) over the last two years (November 2012 to November 2014) were included in the study. A total of 1334 cases were referred for electrophoresis, out of which 830 samples were for serum protein electrophoresis. Major diseases diagnosed were infections/inflammation (42.4\%), nephrotic syndrome (17.1\%), liver disorders (7.1\%), and multiple myeloma (6.4\%). The main clinical presentation was acute renal failure preceding the diagnosis of myeloma. Hence it is necessary to look for potential renal impairment in myeloma patients.
\end{abstract}

Keywords: electrophoresis; renal failure; paraproteinemias; nephrotic syndrome; myeloma

\section{Introduction}

Protein electrophoresis is a well-established, inexpensive technique used for separating proteins based on their net charge, size, and shape. It is a routinely used in clinical laboratories for screening protein abnormalities in various biological fluids (serum, urine, CSF). Many sub specialties include serum protein electrophoresis has been performed as a screening tool in the evaluation of numerous clinical conditions [1, 2]. Generally serum protein electrophoresis is considered for a patient with an elevated total protein, especially those with elevated globulin levels relative to albumin, or any signs and symptoms suggestive of an underlying plasma cell disorder such as multiple myeloma, Waldenstrom's macroglobulinemia, or primary amyloidosis. Evaluation of patients with chronic kidney disease (CKD) also typically includes serum and urine protein electrophoresis $[3,4]$. Recent guidelines from the International Myeloma Working Group have recommended the use of serum protein electrophoresis, immunofixation electrophoresis (IFE) and free light chain assay (FLC) as the screening panel unless primary amyloidosis is suspected $[5,6]$. Serum protein electrophoresis (SPEP) and urine protein electrophoresis (UPEP) are routinely performed for baseline assessment of the amount and type of the myeloma, serial monitoring the rate and level of response and for assessment of possible disease progression or relapse $[7,8]$. Hence this retrospective study was undertaken to analyze the pattern of electrophoretic results at our exclusive nephrourology referral centre.

\section{Subjects and methods}

A retrospective analysis of all the patients who had been referred for electrophoresis (SPEP and UPEP) to Institute of NephroUrology, Bangalore over the last two years (November 2012 to November 2014) was planned and included in the study.

Baseline demographics, clinical history of the patients along with routine urine examination and biochemical parameters at the time of presentation/ biopsy were also analyzed. Creatinine clearance ( $\mathrm{CrCl}$ ) was estimated in all the patients by modification of diet in renal disease (MDRD) formula by an online calculator [9].

A total of one thousand three hundred and thirty four (1334) cases referred for electrophoresis to laboratory of our

*Corresponding author: Dr. Sujatha Siddappa, Department of Pathology, Institute of NephroUrology, Bangalore, Karnataka State, 560002, India. Email: sujathasiddappa@gmail.com

Received 16 April 2015 Revised 16 June 2015 Accepted 24 June 2015 Published 31 June 2015

Citation: Kowsalya R, Sujatha S. A review of electrophoretic patterns from a tertiary care nephrourology referral centre. J Cancer Res Ther. 2015; 3(6):7276. DOI:10.14312/2052-4994.2015-10

Copyright: (C) 2015 Kowsalya R, et al. Published by NobleResearch Publishers. This is an open-access article distributed under the terms of the Creative Commons Attribution License, which permits unrestricted use, distribution and reproduction in any medium, provided the original author and source are credited. 
tertiary care referral centre were included in the study. Out of 1334 samples, 87 samples were excluded from the study due to hemolysed or insufficient samples. In the remaining 1257 samples, 830 were tested for serum electrophoresis and 427 were tested for urine electrophoresis. For serum electrophoresis, $5 \mathrm{ml}$ blood was drawn in plain tube and sera was separated after the sample had clotted and stored till further analysis. While for urine electrophoresis $50 \mathrm{ml}$ of random urine sample was collected and stored for analysis. Agarose gel electrophoresis was carried out in batches on SAS-MX SP-10 SB kit and result interpretation was done using Platinum software PT version 3.0 from Helena Biosciences (UK). Total serum protein was estimated by biuret method and urine protein was determined by dye-binding method.

The raw data was entered and analyzed on GraphPad software. The mean values of the different parameters were compared between normal and myeloma patients. P-values were compared to detect significant statistical differences between mean values at a level of $p<0.05$.

\section{Results}

A total of 830 serum samples were analysed by protein electrophoresis, out of which 20 samples were either insufficient or haemolysed hence ruled out for further analysis. Out of remaining 810 cases, 79 cases were consistent with normal pattern. (Description of normal pattern is required). The Major diseases diagnosed were chronic infections/inflammation (42.4\%), nephrotic syndrome (17.1\%), liver disorders (7.1\%), and myeloma $(6.4 \%)$ in analysed serum samples.

There was a decrease in all parameters of protein band pattern in forty six cases suggesting hemodilution or malnutrition while decreased total protein with low
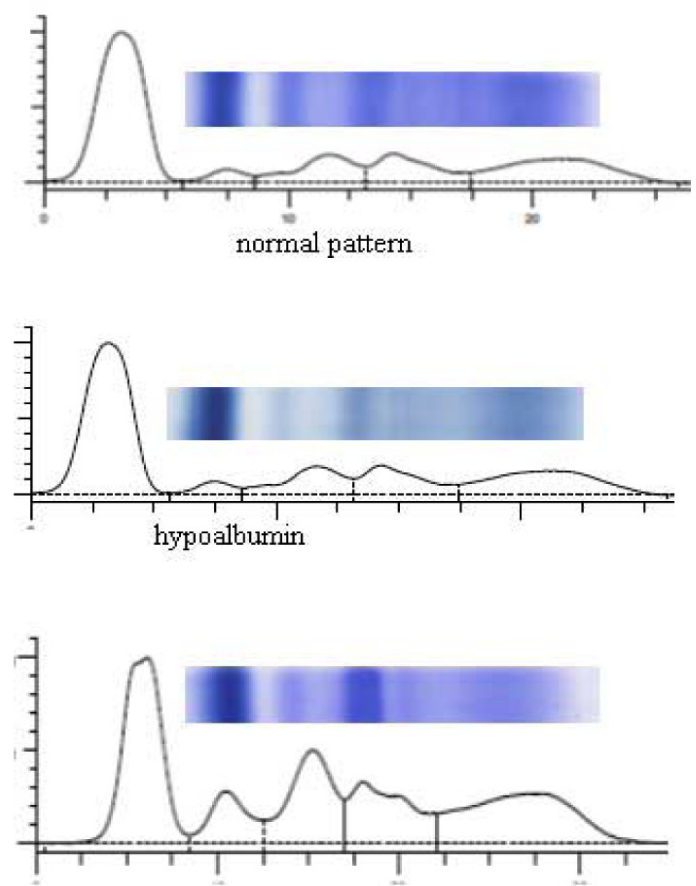

prominent alpha- 2 band albumin and $\gamma$-globulin seen in 112 cases suggesting mild protein loss with hypogammaglobinemia $(<0.7 \mathrm{~g} / \mathrm{dL})$.

Increased alpha-1 and alpha-2 globulins, decreased albumin and transferrin, consistent with acute inflammation was seen in thirty six cases. Increased alpha-2 globulin and C3 band suggestive of sub-acute inflammation in forty nine cases.

Decreased albumin and haptoglobin with a polyclonal increase in $\gamma$-globulins and beta-gamma bridging consistent with liver disease was present in fifty two cases. Very low albumin, transferrin and gamma globulin with increased alpha-2 globulin suggestive of protein loss pattern due to renal disease (nephrotic syndrome) was observed in 122 cases.

Polyclonal increase in immunoglobulins due to autoantibodies was seen in autoimmune diseases such as lupus erythematosus, progressive systemic sclerosis, rheumatoid arthritis were seen in 164 cases. While sixty patients clinically suspected for myeloma revealed a pattern of consistent with polyclonal increase in gamma globulins due to bacterial infections, sero positive individuals with HIV, viral hepatitis, meningitis or autoimmune diseases consistent with chronic inflammation//infection. The polyclonal gamma-globulinemia is characteristic of chronic inflammatory condition generally created by viral infection. Hypogammaglobulinemia $(<0.7 \mathrm{~g} / \mathrm{dL})$ due to chronic lymphoproliferative conditions, immune deficiency, chemotherapy or B-cell neoplasm or due to corticosteroids and immuno suppressive treatments seen in forty nine cases.

Serum protein electrophoresis (Figure 1) revealed a localized band in agarose gel or a sharp peak in the densitometer tracing in 47 patients consistent with finding
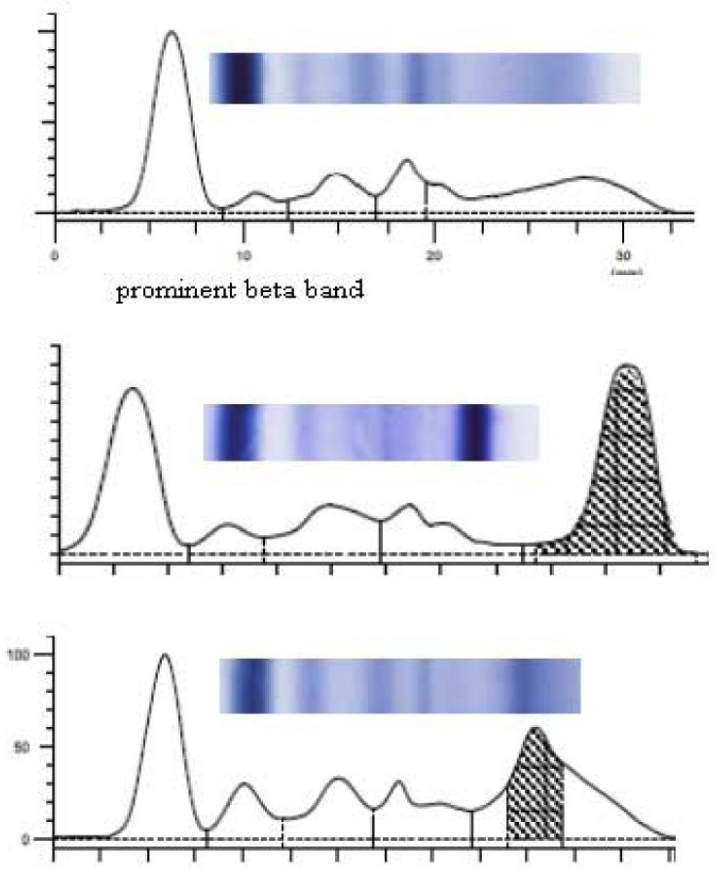

M-band

Figure 1 Showing the different pattern of serum electrophoresis. 
of multiple myeloma. The band migrated in the gamma zone in $66 \%$, beta zone in $21 \%$, between alpha- 2 and beta zones in $12 \%$ and alpha-1 zone in $1 \%$. The concentration of the serum M-protein was lower than $1.0 \mathrm{~g} / \mathrm{dL}$ in $8 \%$ of patients and was lower than $3 \mathrm{~g} / \mathrm{dL}$ in 34\% and remaining patients had a peak more than $3 \mathrm{~g} / \mathrm{dl}$. The comparative data between normal and myeloma patients is shown in Table-1.

Table 1 showing the demographics and laboratory results (mean \pm standard deviation).

\begin{tabular}{lccc}
\hline Demographics & Normal & Myeloma & $p$ \\
\hline Age (years) & $61.2 \pm 10.8$ & $58.4 \pm 10.8$ & NS* \\
Hemoglobin $(\mathrm{g} / \mathrm{dL})$ & $8.58 \pm 1.46$ & $9.2 \pm 1.87$ & $\mathrm{NS}$ \\
ESR (mm/Hour) & $115 \pm 34$ & $105 \pm 30$ & $\mathrm{NS}$ \\
Serum creatinine $(\mathrm{mg} / \mathrm{dL})$ & $5.26 \pm 2.45$ & $3.95 \pm 2.29$ & $\mathrm{P}<0.05$ \\
Total protein $(\mathrm{g} / \mathrm{dL})$ & $7.79 \pm 1.88$ & $6.68 \pm 0.92$ & $\mathrm{P}<0.05$ \\
Urine Protein $(\mathrm{mg} / \mathrm{dL})$ & $63.5 \pm 32.4$ & $49.83 \pm 34.75$ & $\mathrm{P}<0.05$ \\
\hline
\end{tabular}

Abbreviations: *NS = not significant

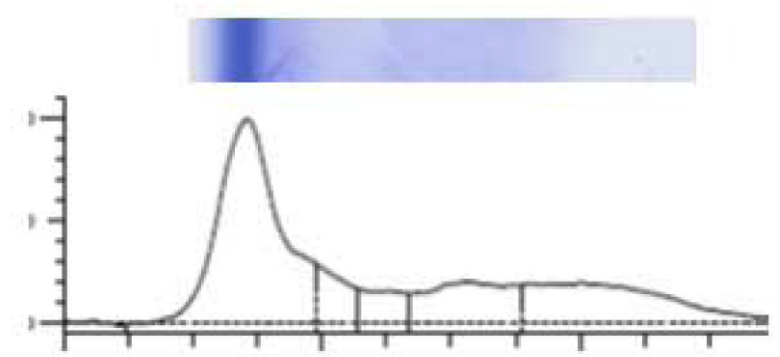

Albumin band

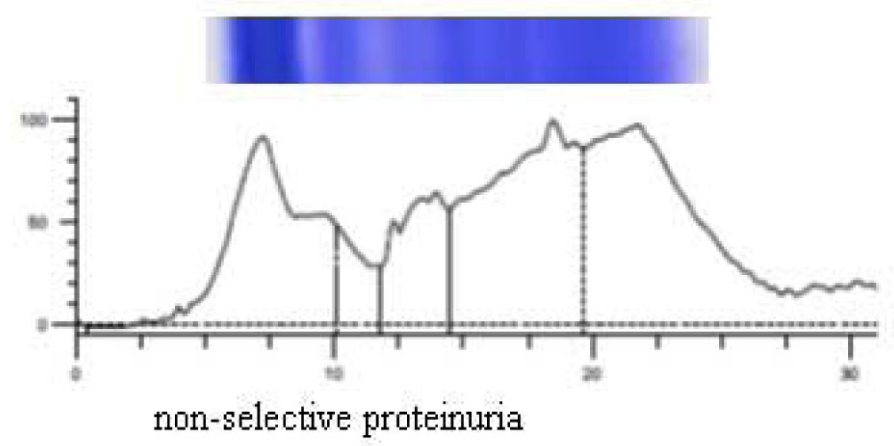

Figure 2 Showing the different pattern of urine electrophoresis.

Renal disease was present in all patients before the diagnosis of myeloma. Renal diseases consisted of mainly acute renal failure (44\%), chronic renal failure $(40 \%)$ and nephrotic syndrome (16\%). After confirmation of myeloma, the patients were referred for chemotherapy with supportive therapy and hemodialysis. More than half of the total number of patients did not complete chemotherapy because of death or lost to follow-up.

\section{Discussion}

Multiple myeloma is a haematological malignancy characterized by a clonal proliferation of malignant plasma cells in the bone marrow secreting a monoclonal immunoglobulin. This malignancy accounts for approximately $1 \%$ of neoplastic diseases and $13 \%$ of hematologic cancers. Complications include neurologic
Electrophoresis of urine (Figure 2) was performed in 494 patients among them 67 samples were not received mainly from patients with end stage renal disease. Apparently no bands were seen in forty two cases while fifty five cases showed a faint albumin peak with faint bands of several minor proteins suggestive of physiological proteinuria. In ninety seven patients, the urine pattern consisted mainly of albumin and faint transferrin band characteristic of nephrotic syndrome. In majority of cases (149 cases) a non-selective pattern similar to the serum pattern was seen in patients with primary glomerulonephropathies, diabetes mellitus, amyloidosis, collagen diseases. Tubular pattern of proteinuria where albumin is not prominent but alpha-1 \& 2 and gamma globulins predominate was seen in forty seven cases. Six cases showed pattern of dysglobulinemia with one or more bands in gamma region due to intact immunoglobulin, free light chains. Among the forty seven patients with a monoclonal light chain in serum electrophoresis thirty one cases showed an M spike in the urine also.

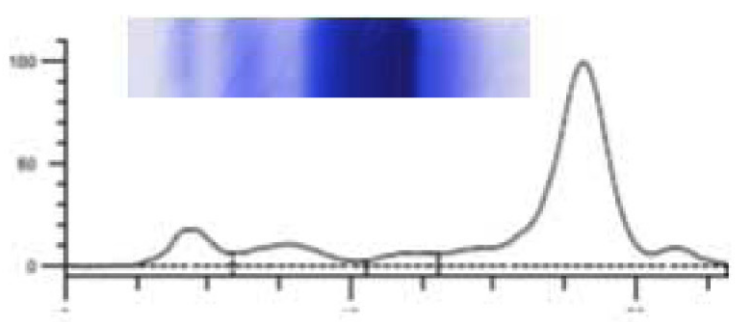

M-band

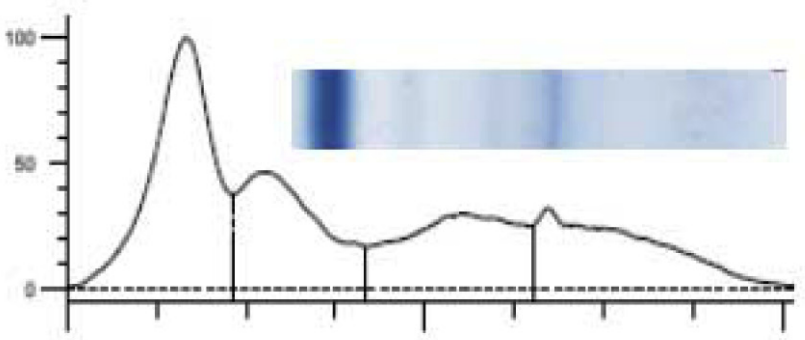

proteinuria with dysglobulinemia

and hematologic origin, infections, renal insufficiency and lytic bone lesions $[10,11]$. The reported incidence in North America is 4.8 per 100000 population for men and 3.3 per 100000 for women. In India the exact incidence in is not known but based on data available from 6 populationbased cancer registries (covering $<0.3 \%$ of the population), the reported incidence varies from 0.3 to 1.9 per 100000 for men and 0.4 to 1.3 per 100000 for women [12]. As a study conducted in an exclusive renal referral centre, protein electrophoresis is commonly used test to identify patients with multiple myeloma and other disorders of serum protein. In our study, we found $6.4 \%$ cases of myeloma due to the fact that study was undertaken an exclusive nephrourology referral centre.

The diagnosis of multiple myeloma is based on certain clinical and laboratory findings such as: presence of 
skeletal lesions (e.g., lytic lesions, diffuse osteopenia, vertebral compression fractures), anemia, pancytopenia, hypocalcemia and renal disease [13]. The laboratory diagnosis requires $\geq 10 \%$ plasma cell involvement in bone marrow biopsy and M-protein spike in the gamma region with concentration greater than $3 \mathrm{~g}$ per $\mathrm{dL}$ in electrophoresis. An additional point considered is size of the M-protein spike. Although spike is usually greater than $3 \mathrm{~g}$ per $\mathrm{dL}$ in patients with multiple myeloma, up to one fifth of patients may have an M-protein spike of less than $1 \mathrm{~g}$ per $\mathrm{dL}$. Thus, the size of the M-protein spike is not helpful in excluding multiple myeloma [14]. In our study, all patients had renal failure with anemia and ' $M$ ' spike in serum electrophoresis.

Most of the myeloma patients have a large amount of Bence-Jones protein (monoclonal free kappa or lambda chain) in their urine and may not have an M-protein spike in serum protein electrophoresis. Consequently, urine protein electrophoresis is recommended for all patients suspected of having a plasma cell dyscrasia. In one series, serum protein electrophoresis showed a spike or localized band in only 82 percent of patients with multiple myeloma. The remainder had hypogammaglobulinemia or a normalappearing pattern [15]. In our study, all the myeloma patients showed a spike or localized band on serum protein electrophoresis and spike in urine electrophoresis from the respective patients.

The kidney acts as a filter, eliminating only a few molecules and leaving most of the proteins in the bloodstream. Renal failure in myeloma is due to an elevated serum concentration of monoclonal free light chains which affect the glomerular basement membrane, tubules, or the interstitium. Free light chains from the circulation are filtered by glomerular filtration and either pass directly into the tubules or are transported into the mesangium. These may deposit along the glomerular basement membrane or within the tubular basement membrane, either in the form of fragments or intact chains. Their deposition leads to obstruction, amyloid formation, and inflammation [16].

The most common causes of renal failure in multiple myeloma are due to: Monoclonal immunoglobulin deposition disease due to deposition of light chains (LCDD) or heavy chains (HCDD). AL amyloidosis where the light chains form beta pleated sheets which deposit in the renal blood vessels or glomeruli. Cast nephropathy is due to the formation of casts in the distal tubules, caused by the deposition of light chains and Tamm-Horsfall protein leading to secondary tubulointerstitial nephritis.

While LCDD and amyloidosis tend to result in chronic kidney disease, often with nephrotic range proteinuria, cast nephropathy will usually present with a sudden rise in creatinine representing an acute kidney injury. A cast nephropathy occurs secondary to aggravating factors, such as dehydration, hypercalcemia, nephrotoxic drugs, or inter current infections. In a native renal biopsy study of patients with multiple myeloma, cast nephropathy was found to be the most common renal manifestation, occurring in $40 \%-63 \%$ of patients, followed by LCDD in $19 \%-26 \%$, and $\mathrm{AL}$ amyloidosis in $7 \%-30 \%$. Therefore, it is necessary to rapidly reduce blood levels of free light chains in order to facilitate the recovery of renal function. Up to $50 \%$ of newly diagnosed patients present with decrease in GFR and many require dialysis. Despite progress in therapy regimes, the median survival rates of myeloma patients with conventional treatment remain no more than $2-3$ years $[17,18]$.

At least half of the patients with multiple myeloma will develop renal failure through the course of their disease. In our study, we found 47 cases of multiple myeloma presenting with renal failure in accordance with previous studies [19, 20]. Approximately $20 \%$ of patients with newly diagnosed myeloma present with renal failure and is second most common cause of death in these patients. In our study all the patients presented with renal failure before myeloma was diagnosed. Majority of the cases had acute renal failure (44\%) followed by chronic renal failure (40\%) and nephrotic syndrome (16\%). The United Kingdom Medical Research Council Multiple Myeloma trials between 1980 and 2002, results showed that renal failure contributed to $28 \%$ of documented early mortality. At diagnosis, $30 \%-40 \%$ of patients had serum creatinine above the upper limit of normal, and up to $10 \%$ of these patients required dialysis. Half of these patients will respond to supportive treatment with reversibility of renal impairment, but 2\%-12\% will progress to end stage renal disease (ESRD) and require dialysis [21].

Monoclonal gammopathy is present in up to 8 percent of healthy geriatric patients. Conté, et al. found that renal failure was related to advanced disease stage and proportion of patients with renal failure was found to increase with advancing age [22]. In our study the mean age of myeloma patients presenting with renal failure was higher than the patients without myeloma. Development of unexplained renal failure in an elderly individual, in association with disproportionate anemia even in absence of skeletal lesions should alert the physician to the diagnosis of multiple myeloma.

While in multiple myeloma, electrophoresis is the accepted method for monitoring the clinical course of myeloma and monitoring for para proteins. The UK National Kidney Federation and UK CKD guidelines recommend that 'patients with CKD should not be subjected to routine myeloma screening prior to referral [23]. Doyle et al have demonstrated that serum electrophoresis is not useful as a screening test to identify myeloma in patients with chronic kidney disease [24]. Our results suggest that serum electrophoresis especially in patients with unexplained renal impairment, is of utmost importance. As acute renal failure is the most common renal disease preceding the diagnosis of myeloma in our series, it is necessary to look for potential renal impairment in myeloma patients as reversal of renal function can be achieved with chemotherapy and haemodialysis treatment [25].

\section{Conclusion}

As acute renal failure is common renal disease preceding the diagnosis of myeloma, serum electrophoresis as an inexpensive and widely available test should be used as an screening test routinely especially in patients with renal impairment. 


\section{Acknowledgements}

We sincerely acknowledge the kind support of Dr. Umesh L, Prof \& HOD of Nephrology, and all the staff of Nephrology department at Institute of Nephrourology. We also acknowledge and thank Dr. C. S. Rathkal, Director of Institute of Nephrourology for his constant support in all our academic endeavors.

\section{Conflict of interest}

Authors declare no conflict of interest.

\section{References}

[1] Vavricka SR, Burri E, Beglinger C, Degen L, Manz M. Serum protein electrophoresis: an underused but very useful test. Digestion. 2009; 79(4):203-210.

[2] O'Connell TX, Horita TJ, Kasravi B. Understanding and interpreting serum protein electrophoresis. Am Fam Physician. 2005; 71(1):105112.

[3] Chan DT, Craig K, Donovan K, Phillips A. Myeloma renal disease: presentation and outcome.. Nephron Clin Pract. 2006; 104(3):c126c131.

[4] Kyle RA. Sequence of testing for monoclonal gammopathies. Arch Pathol Lab Med. 1999; 123(2):114-118.

[5] Katzmann JA, Kyle RA, Benson J, Larson DR, Snyder MR, et al. Screening panels for detection of monoclonal gammopathies. Clin Chem. 2009; 55(8):1517-1522.

[6] Smith A, Wisloff F, Samson D, UK Myeloma Forum; Nordic Myeloma Study Group. Guidelines on the diagnosis and management of multiple myeloma 2005. Br J Haematol. 2006; 132(4):410-451.

[7] Dispenzieri A, Gertz MA, Therneau TM, Kyle RA. Retrospective cohort study of 148 patients with polyclonal gammopathy. Mayo Clin Proc. 2001; 76(5):476-487.

[8] Levey AS, Coresh J, Greene T, Stevens LA, Zhang YL, et al. Using standardized serum creatinine values in the modification of diet in renal disease study equation for estimating glomerular filtration rate. Ann Intern Med. 2006 15; 145(4):247-254.

[9] Kyle RA, Gertz MA, Witzig TE, Lust JA, Lacy MQ, et al. Review of 1027 patients with newly diagnosed multiple myeloma. Mayo Clinic Proc. 2003; 78(1):21-33.

[10] Adams RA, Smith L, Pickering PE. The incidence of monoclonal proteins during 7 years of screening in a District General Hospital. Immunol. 1984; 51(3):451-454.

[11] Alexanian R, Weber D, Liu F. Differential diagnosis of monoclonal gammopathies. Arch Pathol Lab Med. 1999; 123:108-13.

[12] Cohen DJ, Sherman WH, Osserman EF, Appel GB. Acute renal failure in patients with multiple myeloma. Am J Med. 1984; 76(2):247-256.

[13] Hughes $M$, Davidson DF, McColl M. Outcomes of discretionary laboratory requesting of serum protein electrophoresis. Ann Clin Biochem. 2006; 43(Pt 5):372-374.

[14] Paueksakon P, Revelo MP, Horn RG, Shappell S, Fogo AB. Monoclonal gammopathy: significance and possible causality in renal disease. Am Jidney Dis. 2003; 42(1): 87-95.

[15] Rayner HC, Haynes AP, Thompson JR, Russell N, Fletcher J. Perspectives in multiple myeloma: survival prognostic factors and disease complications in a single center between 1975 and 1988. Q J Med. 1991; 79(290):517-525.

[16] Davenport A, Merlini G. Myeloma kidney: advances in molecular mechanisms of acute kidney injury open novel therapeutic opportunities. Nephrol Dial Transplant. 2012; 27(10):3713-3718.

[17] Bansal T, Garg A, Snowden JA, Mckane W. Defining the role of renal transplantation in the modern management of multiple myeloma and other plasma cell dyscrasias. Nephron Clin Pract 2012; 120(4):c228c235.

[18] Greipp PR, San Miguel J, Durie BG, Crowley J, Barlogie B, et al. International staging system for multiple myeloma. J Clin Oncol. 2005; 23(15):3412-3420.

[19] Katzmann JA, Clark RJ, Abraham RS, Bryant S, Lymp JF, et al. Serum reference intervals and diagnostic ranges for free kappa and free lambda immunoglobulin light chains: relative sensitivity for detection of monoclonal light chains. Clin Chem. 2002; 48(9):1437-1444.
[20] Bradwell AR, Carr-Smith HD, Mead GP, Tang LX, Showell PJ, et al. Highly sensitive, automated immunoassay for immunoglobulin free light chains in serum and urine. Clin Chem. 2001; 47(4):673-680.

[21] Beetham R, Wassell J, Wallage MJ, Whiteway AJ, James JA. Can serum free light chains replace urine electrophoresis in the detection of monoclonal gammopathies? Ann Clin Biochem. 2007; 44(Pt 6):516522.

[22] Conté L G, Figueroa M G, Lois V V, Cabrera C ME, León R A, et al. Clinica features and survival of Chilean patients with multiple myeloma. Rev Med Chil. 2007; 135(9):1111-1117.

[23] Kyle RA, Therneau TM, Rajkumar SV, Larson DR, Plevak MF, et al. Incidence of multiple myeloma in Olmsted County, Minnesota: Trend over 6 decades. Cancer. 2004; 101:2667-2674.

[24] Doyle A, Soutar R, Geddes CC. Multiple myeloma in chronic kidney disease. Utility of discretionary screening using serum electrophoresis. Nephron Clin Pract. 2009; 111(1):c7-c11.

[25] Kyle RA, Greipp PR. "Idiopathic" Bence Jones proteinuria: long-term follow-up in seven patients. N Engl J Med. 1982; 306(10):564-567. 